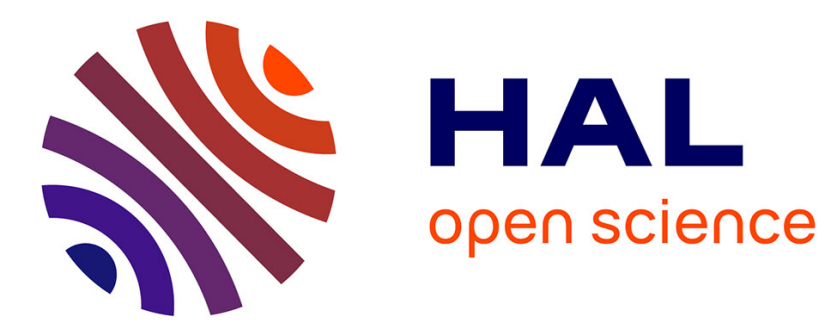

\title{
Influence of temperature and humidity on the activity of three Carabus species \\ Gabriel Nève
}

\section{To cite this version:}

Gabriel Nève. Influence of temperature and humidity on the activity of three Carabus species. Carabid Beetles: Ecology and Evolution, 51, 1994, Series Entomologica. hal-02367195

\section{HAL Id: hal-02367195 \\ https://hal-amu.archives-ouvertes.fr/hal-02367195}

Submitted on 17 Nov 2019

HAL is a multi-disciplinary open access archive for the deposit and dissemination of scientific research documents, whether they are published or not. The documents may come from teaching and research institutions in France or abroad, or from public or private research centers.
L'archive ouverte pluridisciplinaire HAL, est destinée au dépôt et à la diffusion de documents scientifiques de niveau recherche, publiés ou non, émanant des établissements d'enseignement et de recherche français ou étrangers, des laboratoires publics ou privés. 
Nève, G. 1994. Influence of temperature and humidity on the activity of three Carabus species. In Carabid Beetles: Ecology and Evolution, Desender, K., Dufrêne, M., Loreau, M., Luff, M.L. \& Maelfait, J.P. (eds), Kluwer, Dordrecht, 189-192.

\title{
Influence of temperature and humidity on the activity of three Carabus species
}

\author{
G. NÈVE \\ Unité d'Écologie et de Biogégraphie, Université Catholique de Louvain, Croix du Sud 5, B-1348 \\ Louvain-la-Neuve, Belgium
}

\section{Summary}

Carabid beetles were trapped in summer 1987 and spring 1988 in the Plateau des Tailles (Province Luxembourg, Belgium). The traps were checked every morning during 10 trapping sessions (79 days). Temperature and humidity were recorded continuously on the site during the whole period. The influence of these two meteorological variables was studied using a Stepwise Linear Regression Model in order to study the information added by the different variables.

In spring, the higher the mean daily temperature, and the lower the day-night temperature contrast and the mean daily humidity, the more Carabus problematicus and $C$. auronitens were active.

The activity of Carabus problematicus and $C$. auronitens in summer, and of $C$. violaceus in spring was positively correlated with the mean daily temperature.

C. violaceus is active in spring mainly in nights during which the humidity at midnight is between 85 and $97 \%$.

\section{Introduction}

Most studies on the influence of temperature and humidity on carabids' activity have been conducted in the laboratory, and have shown that both factors may show distinctive influences; e.g. Carabus problematicus displayed different activity patterns at $90 \%$ and at $95 \%$ humidity levels (Thiele 1977), but Weber (1983) already mentioned the difficulty of applying laboratory results of $C$. problematicus locomotion records to natural situations.
The influence of temperature, as the most important meteorological variable, on the activity of carabid beetles has been studied in the field by several authors (e.g. Althoff et al. 1994), but humidity, as an important second variable, has generally been discarded, as in the case of the negative interrelationship observed between temperature and humidity in open habitats (e.g. Desender 1983). The use of a Stepwise Linear Regression Model, however, allows the additive significant information given by different variables to be studied (Berenson et al. 1983).

\section{Materials and methods}

During a recent study of the movements of $C$. auronitens and $C$. problematicus (Nève \& Baguette 1990), temperature and humidity were recorded on the site of capture in order to study their effects on the catchability, taken as an index of the activity of the studied species. A total of 147 pitfall traps were put in a beech forest (Luzulo-Fagetum) in the Plateau des Tailles $\left(50^{\circ}\right.$ $15^{\prime} \mathrm{N}, 5^{\circ} 44^{\prime} \mathrm{E}$, Province Luxembourg, Belgium). The pitfall traps consisted of half plastic bottles $17 \mathrm{~cm}$ height, $8.5 \mathrm{~cm}$ diameter, buried so that their rim was at the same level as the surrounding soil surface, as described by Dufrêne (1988). Temperature and humidity were recorded continuously with a mechanical thermo-hydrometer placed on the ground, and the traps were checked every morning one out of two weeks from 22 July to 19 September 1987, and from 20 April to 8 July 1988. At the beginning of the latter period 24 extra traps were set, raising the total to 171 . Totals of 87 and 295 catches of $C$. auronitens, 568 and 96 catches of $C$. problematicus and 43 and 25 
Table 1. Variables most correlated with the daily catches, as chosen by a Stepwise Linear Regression Model; the variables are selected as long as they meet a $0.05 \%$ level for entry in the model. TP1 and TP2 denotes the first two axes of the Principal Component Analysis of the temperature variables, and HP1 the first one of the PCA on humidity

Carabus problematicus

Summer 1987 ( 9 August-19 September) $n=20$

Variables Parameter Partial $R^{2}$ F estimate

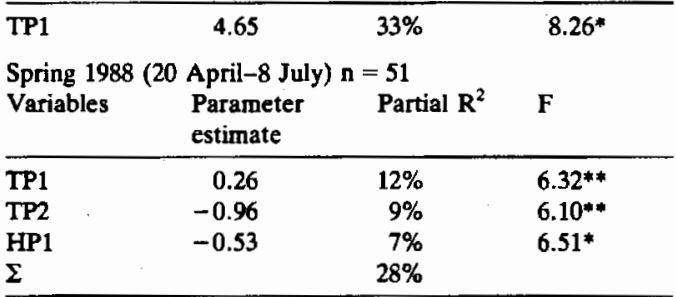

Carabus auronitens

Summer 1987 (22 July-4 September) $n=26$

\begin{tabular}{lccc} 
Variables & $\begin{array}{l}\text { Parameter } \\
\text { estimate }\end{array}$ & Partial $\mathbf{R}^{2}$ & $\mathbf{F}$. \\
\hline TP3 & -1.18 & $27 \%$ & $7.72^{*}$ \\
TP1 & 0.21 & $30 \%$ & $12.94^{* * *}$ \\
$\Sigma$ & & $57 \%$ &
\end{tabular}

Spring 1988 (20 April-23 June) $n=41$

\begin{tabular}{lcrl} 
Variables & $\begin{array}{l}\text { Parameter } \\
\text { estimate }\end{array}$ & Partial R $^{2}$ & $\mathbf{F}$ \\
\hline TP1 & 1.39 & $35 \%$ & $20.22^{* * *}$ \\
HP1 & -1.55 & $14 \%$ & $17.24^{* * *}$ \\
TP2 & -2.72 & $7 \%$ & $14.92^{* * *}$ \\
$\Sigma$ & & $56 \%$ & \\
\hline
\end{tabular}

Carabus violaceus

Spring 1988 (11 June-8 July) n = 41

$\begin{array}{llll}\text { Variables } & \begin{array}{l}\text { Parameter } \\ \text { estimate }\end{array} & \text { Partial } R^{2} & F\end{array}$

\begin{tabular}{llll}
\hline TP1 & 0.11 & $24 \%$ & $11.89^{* *}$
\end{tabular}

*p $<0.05,{ }^{* *} p<0.01, * * * p<0.001$.

C. violaceus were recorded in summer 1987 and spring 1988, respectively. During the whole period there were 29 and 50 capture days, grouped in 10 trapping sessions.

\section{Statistical analysis and results}

For the statistical analysis, the values of temperature and humidity were input at 2 hourly in-

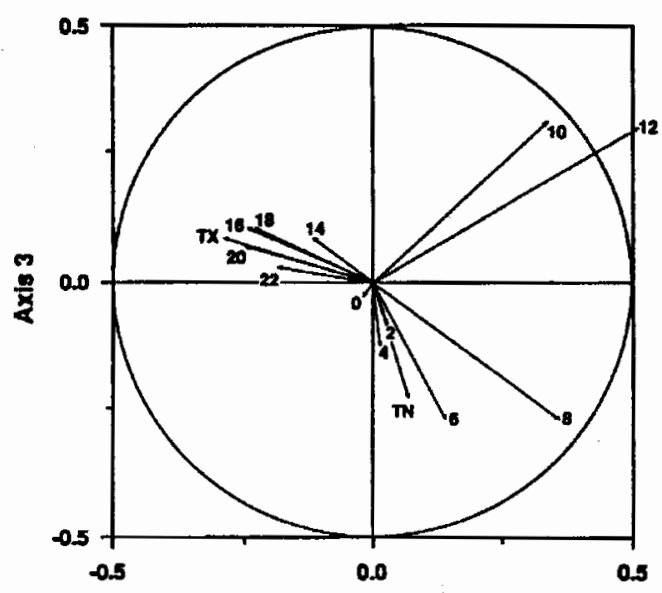

Axls 2

Fig. 1. Equilibrium circle of the temperature descriptors, as given by axes 2 and 3 of the Principal Component Analysis of the temperatures of the $\mathbf{2 4}$ hours preceding the trap check ( 8.00 a.m.). TN and TX are the minimum and maximum observed temperarures and the figures the different times of observation.

tervals, as well as the maximum and minimum of each 24 hour period preceding the trap check (8.00 a.m., West European Summer Time). As the studied species show marked seasonal differences in their activity, $C$. problematicus being an autumn breeder (Houston 1981) and $C$. auronitens a spring breeder (Hemmer et al. 1986), the data sets from summer 1987 and spring 1988 were analysed separately. As the 14 daily values of each temperature and humidity were correlated with each other, the multiple linear regression method could not be used on the raw data, because of the colinearity of the independent variables (Legendre \& Legendre 1984). The influences of temperature and humidity were analysed separately because there were only occasional correlation values (mostly $\mathrm{P}>0.10$ ) between these two sets of variables, in contrast to the high correlation of both temperature and humidity values within each 24 hour period $(P<0.001)$; and a Principal Component Analysis (PCA), after $z$ transformation, on both variables taken together gave a first axis determined mainly by temperature values (percentage of values accounted for $43.6 \%$ ) and a second axis by humidity values 
(a) $\mathrm{N}$

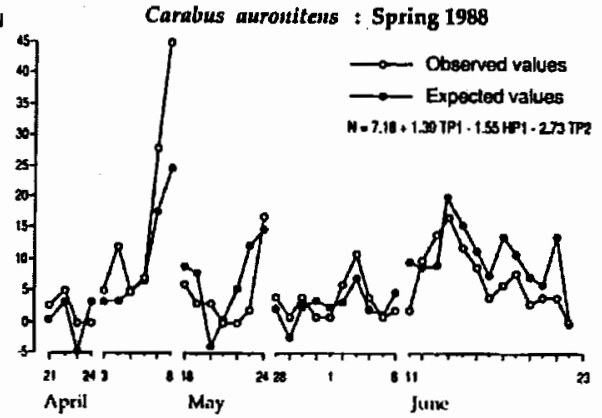

(b)

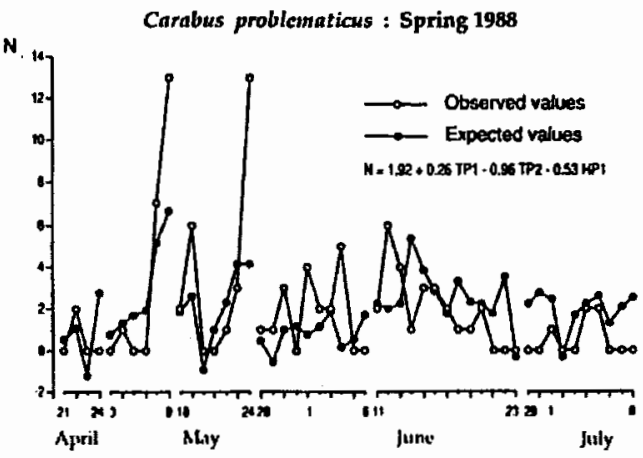

(c)

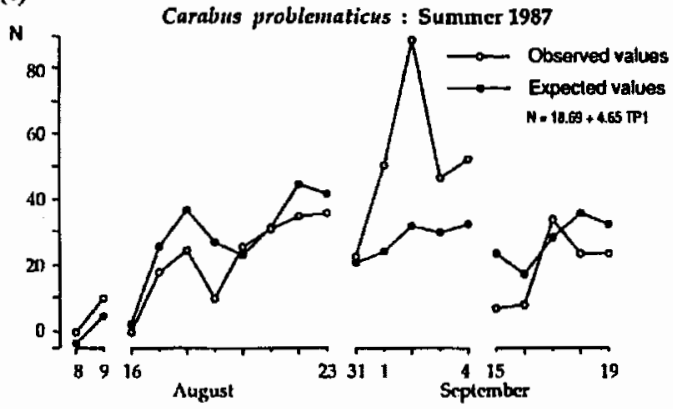

Fig. 2. (a) Spring catches of $C$. auronitens and (b) $C$. problematicus, and $(c)$ summer catches of $C$. problemaricus and their values as predicted by the Stepwise Multiple Linear Regression Model.

(percentage of values accounted for $38.1 \%$ ). The first three axes of the PCAs on these two variables retained 85,8 and $4 \%$ of the variance of the 14 original temperature values; and 72,10 and $6 \%$ of the variance of the original 14 humidity values. During each season, only the periods during which significant numbers of the considered species were continuously caught were kept, in order

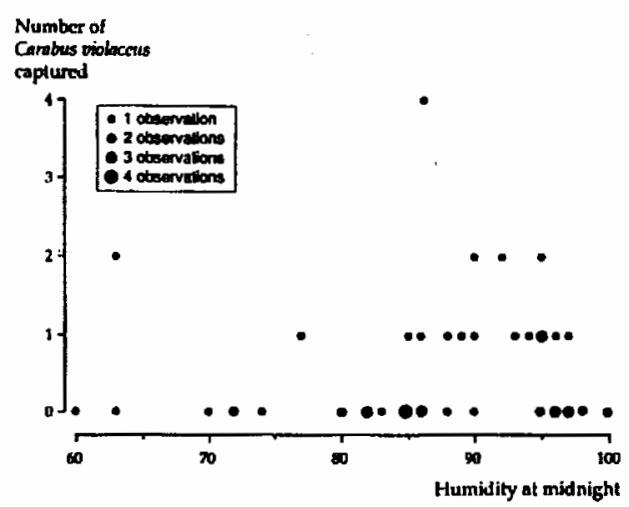

Fig. 3. Spring 1988 catches of $C$. violaceus, as a function of observed humidity at 0.00 the night previous to the trap check.

to account for the seasonality of activity of the different species. The coordinates of the days, given by the first three axes of the PCA on both humidity and temperature were then used in a Stepwise Linear Regression Model (procedure REG, SAS 1990) in order to detect the greatest influences on the daily catches of the studied species (Table 1).

The first two axes of the PCA of temperature values and the first one of humidity values are highly significant in explaining the variation of $C$. problematicus and $C$, auronitens numbers caught in spring. The first axes of both the temperature and the humidity PCAs give indices of the magnitude of the considered temperatures and humidities respectively, the second temperature axis is a measure of the contrast between day and night temperatures and the third axis of the temperature PCA is an index of the difference between late morning and early night temperatures (Fig. 1).

\section{Discussion}

C. problematicus and $C$. auronitens morning spring catches respond positively to the temperatures of the previous 24 hours and negatively to temperature variation and mean humidity values (Table 1). In summer however, as it responds negatively to the contrast between late morning 
and early night temperatures (3rd PCA axis), $C$. auronitens seems to be active preferably in relatively warm early nights, which is in accordance with the observations of Hemmer et al. (1986) who showed that $C$. auronitens is mostly active in early night and that its spring activity is correlated with the temperature at this time (20.00-22.00), which is also true in our case (20.00: $R^{2}=0.21$, $\left.P<0.01,22.00: R^{2}=0.18, P<0.01\right)$. In both spring and summer, as the first axis of the temperature PCA was chosen as the most correlated variable, $C$. auronitens and $C$. problematicus activity depends on the temperatures of the circadian rhythm taken as a whole, even within their preferred season of activity. Using the meteorological variables chosen by the Stepwise Linear Regression Model, it is possible to model the number of captures of the species studied (Fig. 2).

For $C$. violaceus, only the first axis of the PCA temperature analysis showed a good correlation with the numbers caught in spring, discarding any effect of humidity values; this is possibly due to the very low numbers of $C$. violaceus captured. It seems nevertheless that the species responds strongly to humidity levels, as $88 \%$ of the individuals were captured at humidities from 85 to $97 \%$ at midnight in spring 1988 (Fig 3).

This clearly shows that a linear regression is not applicable in all cases. Vogt et al. (1983) showed that several meteorological variables (temperature, wind speed,...) induce positive responses in the catchability of Lucilia cuprina (Calliphoridae), up to a certain level where the catchability levels off. Hemmer et al. (1986) showed the minimum early night temperature at which $C$. auronitens begins to be active in early spring is around $6-7^{\circ} \mathrm{C}$; a lack of cold $\left(<7^{\circ} \mathrm{C}\right)$ period on the study site in April 1988 did not allow the fluctuations of numbers caught above and below this critical temperature to be studied.

\section{Acknowledgements}

Thanks are due to Dr Michel Baguette and Dr Marc Dufrêne for help during the fieldwork and numerous discussions throughout the analysis, and to Luc Renier who drew the figures. Prof. Philippe Lebrun gave his support throughout this work and commented on the manuscript.

\section{References}

Althoff, G.-H., Klenner, M., Niehues, F.-J. \& Weber, F. (1994) Dependance of running activity and reproduction in Carabus auronitens on temperature. This volume.

Berenson, M.L., Levine, D.M. \& Goldstein, M. (1983) Intermediate Statistical Methods and Applications. A Computer Package Approach. Prentice-Hall, Englewood Cliffs, NJ.

Desender, K. (1983) Ecological data on Clivina fossor (Coleoptera, Carabidae) from a pasture ecosystem. I. Adult and larval abundance, seasonal and diurnal activity. Pedobiologia, 25, 157-167.

Dufrêne, M. (1988) Description d'un piège à fosse efficace et polyvalent. Bulletin et Annales de la Societé royale belge d'Entomologie, 124, 282-285.

Hemmer, J., Klenner, M., Niesing, H. \& Weber, F. (1986) Life history phenomena in a subpopulation of Carabus auronitens F. from the Westphalian lowland. Carabid Beetles: their Adaptations and Dynamics (eds P.J. den Boer, M.L. Luff, D. Mossakowski \& F. Weber), pp 439464. Gustav Fisher, Stuttgart.

Houston, W.W.K. (1981) The life cycles and age of Carabus glabratus Paykull and C. problematicus Herbst (Col.: Carabidae) on moorland in northern England. Ecological Eniomology, 6, 263-271.

Legendre, L. \& Legendre, P. (1984) Ecologie Numérique. Vols. 1 \& 2. Masson, Paris.

Nève, G. \& Baguette, M. (1990) Spatial behaviour and microhabitat preferences of Carabus auronitens and Carabus problematicus (Coleoptera, Carabidae). Acta Oecologica, $11,327-336$.

SAS Institute Inc. (1990) SAS/STATB. User's Guide. Version 6, 4th edition. Vol. 2. SAS Institute Inc., Cary, NC.

Thiele, H.U. (1977) Carabid Beetles in their Environments. Springer Verlag, Berlin.

Vogt, W.G., Woodburn, T.L., Morton, R. \& Ellem, B.A. (1983) The analysis and standardisation of trap catches of Lucilia cuprina (Wiedeman) (Diptera: Calliphoridae). Bulletin of Entomological Research, 73, 609-617.

Weber, F. (1983) Die tageszeitliche Aktivitătsverteilung von Carabus problematicus im Laborexperiment und im naturlichen Habitat. The Synthesis of Field Study and Laboratory Experiment, Report 4th Symposium of European Carabidologists (eds P. Brandmayr, P.J. den Boer \& F. Weber), pp. 60-73. Centr. Agr. Publ. Docum. (Pudoc), Wageningen. 